Revue Française de Civilisation Britannique

\title{
Review of Darrell Newton, Paving the Empire Road, $B B C$ Television and Black Britons
}

\section{Olivier Esteves}

\section{(2) OpenEdition \\ Journals}

Édition électronique

URL : https://journals.openedition.org/rfcb/7622

DOI : $10.4000 /$ rfcb.7622

ISSN : 2429-4373

Éditeur

CRECIB - Centre de recherche et d'études en civilisation britannique

Référence électronique

Olivier Esteves, "Review of Darrell Newton, Paving the Empire Road, BBC Television and Black Britons », Revue Française de Civilisation Britannique [En ligne], XXVI-1 | 2021, mis en ligne le 02 décembre 2020, consulté le 05 janvier 2022. URL : http://journals.openedition.org/rfcb/7622 ; DOI : https://doi.org/ $10.4000 /$ rfcb.7622

Ce document a été généré automatiquement le 5 janvier 2022.

\section{(†)

Revue française de civilisation britannique est mis à disposition selon les termes de la licence Creative Commons Attribution - Pas d'Utilisation Commerciale - Pas de Modification 4.0 International. 


\title{
Review of Darrell Newton, Paving the Empire Road, BBC Television and Black Britons
}

\author{
Olivier Esteves
}

\section{RÉFÉRENCE}

Darrell Newton, Paving the Empire Road, BBC Television and Black Britons, Manchester :

Manchester University Press, 2011.

1 In Paving the Empire Road, BBC Television and Black Britons, Darrell Newton provides an insightful, exhaustive analysis of the ways in which the BBC, and beyond it other TV channels, have debated, integrated, projected, stereotyped non-whites on screen. The many references to other channels -notably ITV, Channel Four- in the last chapters are in fact so many pointers to the strong path dependence ${ }^{1}$ on decisions, policies, perceptions, approaches within the BBC, the latter providing in Newton's eyes a 'liberal framework' (p. 9) to promote, for instance, the works of Caribbean artists, writers, etc. This decisive influence over decades has been all the more remarkable as, although often reflecting the prevailing consensus on race and immigration, ${ }^{2}$ the $\mathrm{BBC}$ is analysed here as largely a national institution unto itself, hence, for instance, the virtual absence of references in this book to Prime Ministers from Attlee to Blair.

The book's major asset lies in its thorough investigation into accessible BBC archives on the topic, as well as in interviews with many of the prominent media players in the field, through a longue durée interviewing process that kicked off in 1993 and was terminated in 2010, before the book got published. These two types of sources -archives and ethnography- have allowed Newton to produce a monography which reaches way beyond most analyses of Blackness on screen.

3 For anyone who is not a specialist in the field, what is striking when reading this book is how the $\mathrm{BBC}$, from its very early years, was keenly concerned with giving air-time to 
non-whites and was painfully aware of the problems involved in promoting stereotypical images of those Newton often calls 'hopeful immigrants' or 'hopeful citizens' (i.e. West Indians in Britain). At the same time, and regrettably, the BBC's concerns over these questions seem to have been ongoing for decades: despite the many improvements which are unpacked in the book, it still remains that so much of the writing, so much of the producing, so much of the decision-making process at senior level is still being overwhelmingly -and disproportionately- made by Whites. This is a stubborn fact that is lamented by Stuart Hall, admittedly the most high-profile among the interviewees (p. 202). The corollary dilemma has been, for Blacks, how to elbow their way into mainstream broadcasting whilst being counted and recognized as Blacks, which echoes similar concerns in other fields (multiculturalism, citizenship, welfare provision, etc.). ${ }^{3}$ The challenge was, for Asians, partly a linguistic one : instead of foregrounding their sheer difference by using the Hindustani or Urdu languages in some of its programmes, it was deemed preferable by the BBC to cater to the special needs of Asian immigrants by facilitating their integration into the mainstream, helping Asian women to do their shopping, etc. (Newton, p. 120-122). But even with this concern in mind these needs were still regarded as 'special', which indeed they were.

\section{Race-relations and non-white ordinariness}

4 The book, throughout, offers fascinating insight into the debates, dilemmas, decisions and counter-decisions on programming and race-relations. Although little discussed as a concept in this book, ${ }^{4}$ the phrase itself is nevertheless at the heart of Newton's work. As scholars from Michael Banton to Robert Miles and more recently Barnor Hesse have underlined, "Race relations" is a quite problematic phrase, magnifying what is racebased in social relations at the expense of all the rest. It is generally believed to have emerged in the wake of the 1919 Chicago beach riots, with the establishment of the

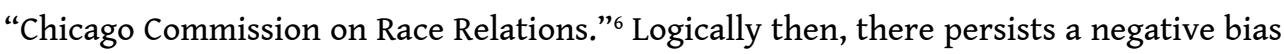
in race relations writings, be it in academia, among policy-makers, and in the media. This is at the very heart of Newton's subject of study : the BBC's challenge has been to not just present inter-racial relations as problematic, hence the focus on riots, racism, discrimination but also as part of the choreography of the everyday in mainstream Britain. All too often, the former is deemed newsworthy rather than the latter, a tendency the BBC bureaucracy has been aware of. "Race relations" is also a shifting signifier, changing alongside the evolution of perceptions : a germane illustration of this is the fear of miscegenation, itself a "race-relations" question debated by Newton through polls and televised debates (p. 56, p. 60) as well as through his very detailed of the -admittedly vastly-researched- Notting Hill and Nottingham riots of $1958 .{ }^{7}$ Whereas in the 1950s and 1960s this was a key concern, today inter-racial unions and marriages are not apprehended from the prism of 'race-relations'. ${ }^{8}$

5 As early as the 1950s, with its acclaimed A Question of Colour, the BBC tried to lay stress on West-Indians as part of British normalcy, as workers (rather than, say, as artists), and investigated some local on-the-ground initiatives to foster what was still known back then as "racial harmony" (see p. 60-77). Also key were BBC efforts to offer a template for non-white perspectives on life in Britain, as early as 1956 with the broadcast A Man from the Sun. Just as important is, in Newton's book, the insistence on Birmingham as a crucial site of non-white representation, programming, broadcasting 
and agency. Not everything is about London, very far from it in fact. The local embeddedness of programming on ethnic minorities and non-white immigrants is a key facet of a question which is also analysed, in this book, as an international relation, colonial and post-colonial issue, connecting the UK with Jamaica, Kenya, the United States, and to a lesser extent South-Africa.

\section{Inside the black box of a patronising, liberal machinery}

6 Truly fascinating are all the analyses of internal memos, surveys, polls conducted with the audience, satisfaction / dissatisfaction indexes on programmes about race even at an early stage (1950s), and more importantly detailed interrogations of debates within the BBC about whether this or that broadcast should be given the go-ahead, or else be trimmed or cancelled, and if so for what reasons. Pivotal in such decision-making processes were academics such as Kenneth Little (Edinburgh University), a central figure in the early years, as well as Michael Banton, E. D. Butterworth or Dipak Nandy, one of the founders of the Runnymede Trust created in $1968 .{ }^{9}$

7 Particularly controversial were broadcasts about racism, which in Newton's account tellingly provide a historical framework to comprehend more recent programmes, such as the much-maligned White Season coinciding, on $\mathrm{BBC2}$, with the $40^{\text {th }}$ anniversary of Enoch Powell's so-called 'Rivers of Blood' speech in $2008,{ }^{10}$ as well as the 2018 reading of Powell's speech by actor Ian McDiarmid (on Radio Four). ${ }^{11}$ These instances all share a commonality : racist hostility is firmly entrenched in the BBC's perception as a white working-class phenomenon.

8 In the late 1940s, some radio programmes were deemed needless because they would only be listened to by Britons who were more educated and therefore, it was argued, less likely to feel prejudice, thus running the risk of 'preaching to the converted' ( $p$. 31-2). More broadly, racism was sometimes seen as sugar-coated because relegated to easily identifiable sections of the (uneducated) public : landladies, publicans, and the uncouth Teddy Boys in the late 1950s (p. 83). This was a far cry from approaching racism as a systemic question, and in this sense Newton's media analysis complements, albeit anecdotally, research on the framing of the white working-classes as knee-jerk racists by sociologists (David Gillborn) as well as historians (Jon Lawrence). ${ }^{12}$ Although the covering of contemporary issues was part of its self-imposed remit, the $\mathrm{BBC}$ proved somewhat reluctant to tackle racism head-on, sometimes because there was a internalised risk of doing more harm than good, or because it was deemed essential to cover racism elsewhere, such as in the United States and Apartheid-mired South-Africa. By and large, the author's conclusion is that in its formative decades the BBC had "a studied, though somewhat patronising, perspective on the issue of race and immigrants" (p. 104).

\section{"As diverse as a packet of crisps"}

9 All in all, there is in the book a much more sustained focus on West-Indians rather than on Asians, and Newton is correct in challenging the phrase "West-Indian", itself reifying, if convenient, lexicon (p. 8). The author does not much underline the lowprofile attitude of most Asians and their reluctance to be in the limelight. This contrasts with Caribbeans who feel British, despite their culture shock upon arrival in 
England, and are more inclined to stake claims through their keen sense of British citizenship. In the last two chapters though, many of the interviewees are of Caribbean origins or of Asian ones, which illustrates a profound change through decades. The frustration was all the stronger, particularly as through the 1990s, there was spate of key reports concluding that overall, ethnic minorities were evidently underrepresented at all echelons of television and that more often than not minority actors were trapped into stereotypical roles. Therein lay a real challenge for, by 2000 , it was estimated that $20 \%$ of TV viewers would be non-white.

Another issue was Americanization, which as a U.S. scholar Newton is painfully aware of (p. 187, 198). This means that role models from Oprah Winfrey to Bill Crosby have for years if not decades drawn attention away from Black British talents. More recently though, in his piece "Airports and auditions", British-Asian actor Riz Ahmed has convincingly claimed that as far as his own career goes, "Americanisation" has proved a game-changer :

The reality of Britain is vibrant multi-culturalism, but the myth we export is an allwhite world of Lords and Ladies. Conversely, American society is pretty segregated, but the myth they export is of a racial melting-pot solving crimes and fighting aliens side by side. So America is where I was headed. ${ }^{13}$

Admittedly, Newton's book was published in 2011, not taking into account certain recent developments, notably as far as the Internet and Netflix are concerned. For all this, his monograph skilfully underlines the extent to which the non-white real or would-be contributors to the British media scene, and to the BBC in particular, are now, to quote an interviewee, as "diverse as a packet of crisps" (p. 193). And as such, the book remains a very valuable study at the crossroads of history, media studies and sociology, adroitly avoiding the pitfalls of "mediacentrism" 14 by interrogating the complexities of the production of representation rather than of its reception. It is a key contribution to the ongoing conversation about race, immigration, the media, stereotyping and empowerment in Britain.

\section{NOTES}

1. Path dependence is now a key concept in the social sciences, originally drawn from economics and political science. Loosely defined, it is about the way social processes, institutional decisions and bureaucratic frames tend to shape, more or less vigorously, processes, decisions and institutions in the future. It is about how institutionally, one thing very often necessarily leads to another, sometimes somewhat independently from the immediate context. On the concept of 'path dependence' in public policies, see Paul Pierson, 'Increasing Returns, Path Dependence and the Study of Politics', in The American Political Science Review, Vol. 94 (2), 2000, pp. 251-267.

2. One salient instance of this was when the $\mathrm{BBC}$ came out against that the exhortation that it should provide information to prospective immigrants from the New Commonwealth, preferring to provide information to those already in Britain, and trying to dissuade prospective migrants, arguing the necessity to 'make it clear that we are not encouraging West Indians to come here, but trying to help those who for their own reasons decide to do so' (Newton, p. 108). 
3. See for instance Anne Phillips, Multiculturalism without Culture, New Jersey: Princeton University Press, 2007 ; Keith Banting, Will Kymlicka (eds.). The Strains of Commitment, Political Sources of Solidarity in Diverse Societies. Oxford : Oxford University Press, 2017 ; Alan W. Wolfe, Jyette Klausen, "Identity Politics and the Welfare State", Social Philosophy and Policy, Vol. 14 (2), 1997, p. 213-255. For a short presentation of those questions in French, see Olivier Esteves, Romain Garbaye, Le Multiculturalisme britannique au 21ème siècle : enjeux, débats, politiques, Paris : Presses de la Sorbonne Nouvelle, 2017.

4. Also regrettably undiscussed as concept is the phrase 'colour-bar' and its colonial ramifications in history.

5. Michael Banton, "The Race Relations Problematic", The British Journal of Sociology, Vol. 42 (1), 1991, 115-130 ; Robert Miles, Racism and Migrant Labour (London : Routledge \& Kegan Paul, 1982) ; Barnor Hesse, (ed.), Un/Settled Multiculturalisms, Diasporas, Entanglements, Transruptions (London, Zed Books, 2000), 11.

6. See Banton, art.cit., p. 115-6; he contends that the phrase originates from a 1911 article on the economic faring of Blacks in various Georgia counties.

7. It is now commonly accepted that fear of miscegenation was a key factor in the sparking of the riots in both places.

8. Miri Song, "Multiracial People and Their Partners in Britain", Ethnicities, Vol. 16 (4), 2016, 631-648.

9. On Dipak Nandy and the foundation of the Runnymede Trust, see Bret Bebber, "The Rise of the Runnymede Trust : Enoch Powell and the Media Wars" in Olivier Esteves, Stéphane Porion (eds.), The Lives and Afterlives of Enoch Powell, Abingdon : Routledge, 2019, p. 81-96.

10. See, for instance, the post by the Institute of Race Relations : https://irr.org.uk/article/ tribalism-and-powellism-infuse-tv-series/

11. See The Guardian, 'BBC under fire over Enoch Powell 'rivers of blood' broadcast', 12. 04. 2018.

12. See David Gilborn, "The White working-class, racism and respectability : victims, degenerates and interest-convergence", British Journal of Educational Studies, Vol. 58 (1), 2010, 3-25; Jon Lawrence, $\mathrm{Me}, \mathrm{Me}, \mathrm{Me}$ ? The Search for Community in Post-War England, Oxford : Oxford University Press, 2019, p. 155-7. Also see Kjartan Páll Sveinsson (ed.), Who Cares About the White WorkingClass? (London: Runnymede Trust, 2009 ) : https://www.runnymedetrust.org/uploads/ publications/pdfs/WhoCaresAboutTheWhiteWorkingClass-2009.pdf (accessed 28. 11. 2020)

13. Nikesh Shukla (ed.), The Good Immigrant, London : Unbound, 2016, p. 162.

14. Mediacentrism loosely defined is a tendency to overplay the role of the media in public opinion, and in people's perceptions. Mediacentrism has been exposed when a national campaign of propaganda has proved fruitless with voters, such as with the 2005 referendum on the European Constitution project in France and the Netherlands.

\section{AUTEURS}

OLIVIER ESTEVES

Université de Lille 